\title{
Scientific Substantiation of the Use of the Environmentally Safe Water-Saving Irrigation System in the Conditions of the Insufficient Wet Area of Azerbaijan
}

\author{
ZH Aliev* \\ Institute of Soil Science and Agrochemistry of the National Academy of Sciences of Azerbaijan, Azerbaijan \\ *Corresponding author: ZH Aliev, Head of Soil Erosion Laboratory, Institute of Soil Science and Agrochemistry of the \\ National Academy of Sciences of Azerbaijan, Azerbaijan
}

\begin{tabular}{|c|c|}
\hline ARTICLE INFO & ABSTRACT \\
\hline Received: 慧 September 19, 2019 & It should be recognized that the Republic of Azerbaijan has a leash of $14 \%$ of the \\
\hline Published: 幽 September 30, 2019 & $\begin{array}{l}\text { water supply in the whole of Transcaucasia. Then, when the interim water balance } \\
\text { of the republic is } 32.29 \text { million km3. However, in the best case, the water years with }\end{array}$ \\
\hline $\begin{array}{l}\text { Citation: ZH Aliev. Scientific Substantiation } \\
\text { of the Use of the Environmentally Safe } \\
\text { Water-Saving Irrigation System in the } \\
\text { Conditions of the Insufficient Wet Area of } \\
\text { Azerbaijan. Biomed J Sci \& Tech Res 21(4)- } \\
\text { 2019. BJSTR. MS.ID.003635. }\end{array}$ & $\begin{array}{l}\text { a } 95 \% \text { supply due to neighboring water atheria, this figure reaches up to } 20 \text { million } \\
\mathrm{km} \text {, as well as in shallow years, the republic will only reduce it to } 17.0 \text { million km } 3 \text {. } \\
\text { water. That is, there is an acute shortage of water in the country. For the rational use } \\
\text { of already limited water resources, it is necessary to switch to modern progressive } \\
\text { irrigation methods using small-scale mechanization and automation of irrigation. The } \\
\text { current technical equipment for irrigation does not always meet the requirements of } \\
\text { the specific conditions of Azerbaijan. Our proposed irrigation system can be successfully }\end{array}$ \\
\hline $\begin{array}{l}\text { Keywords: Stability, Natural Resources, } \\
\text { Environment, Irrigated Agriculture, } \\
\text { Rational Use, Environmentally Friendly }\end{array}$ & $\begin{array}{l}\text { was tested in the country with certifying indicators as crop yields increased to } 38-50 \% \text {, } \\
\text { when irrigation water of } 3 \text { or more was saved times, while maintaining the ecological } \\
\text { balance of the environment. }\end{array}$ \\
\hline
\end{tabular}

\section{Introduction}

The water problem is one of the basic industries, the stability of the entire economy, the livelihoods of the population, and the sustainability of the natural environment in the State depend on its successful functioning.

To ensure food security in Azerbaijan and, as a consequence of their stable socio-economic development, it is necessary to solve the problems of reproduction and conservation, as well as environmental safety in the rational use of water resources. The transition to market relations necessitates a rethinking of the principles and methods for determining the environmental performance of existing industries in the area of irrigated agriculture [1-5].

\section{Research Objectives}

Today's challenge is to achieve a sustainable increase in the productivity of the agricultural system through the adaptation and transfer to production of environmentally sound technology and natural resource management strategies and their conservation. To increase agricultural production in the agricultural system, it is necessary to solve the following tasks:

a. Optimal use of available water and soil resources (natural rainfall and irrigation).

b. Rational use of nutrients.

c. Use of the latest environmentally friendly equipment and technology. 
At the same time, it is extremely necessary to develop specific conditions for the latest environmentally friendly water-saving equipment and irrigation technology.

\section{Study Moves and Discussion of Materials}

Water-intensive crops and water consumption per 1 ha of irrigated land lags due to water shortages, as a result of which, instead of 6-7 waterings, plants receive 2 waterings. On the other hand, Azerbaijan differs in climatic conditions from other regions of the former Soviet Union. That is, 9 out of 11 climatic zones existing in nature takes place in our republic. This circumstance requires a special approach to solving the problems of agricultural production. It should also be noted that the rainfall for different regions is very uneven. So, to meet the needs of crops during their growing season, there is an acute shortage of water. In Azerbaijan, from 1.4 million hectares of irrigated area, $96 \%$ is watered by the surface method. That is, in the republic, progressive technology and irrigation technology are used very little [6-8].

The main condition for conducting natural irrigation along the furrows is a thorough capital planning of the irrigated massifs, as well as the correct cutting of the furrows and the supply of water to them strictly according to the established standards. As a rule, this norm is not maintained in Azerbaijan. It is known that noncompliance with irrigation technology for furrows and inlet leads to large losses of scarce irrigation water, waterlogging, rising groundwater levels, reverse salinization of soil and erosion. All this leads to a significant decrease in agricultural crops, destroys the soil structure, causes the need for additional land reclamation, and even leads to the complete unsuitability of land for agricultural production. Further preservation of such a situation may lead to even more serious consequences in the national economy of the republic. For rational use already insufficient water resources, it is necessary to switch to modern progressive irrigation methods using small-scale mechanization and automation of irrigation. Existing technical means of irrigation do not always meet the requirements of the specific conditions of Azerbaijan.

It should be noted that Azerbaijan is undergoing a transition to multi-structured management. That is, after the reform of almost $100 \%$ of economic activities, more than 35 thousand farms and other private farms were created on their basis, which were granted 1.3 million hectares of land for personal ownership. Of the total agricultural land per capita, one third of the irrigated area is about 0.15 ha. These lands account for about $85 \%$ of all crop production of the republic. The transfer of land to private ownership made it possible to accelerate the development of agricultural production. Existing technological means of irrigation do not always meet the requirements of agricultural production in Azerbaijan. Therefore, there is a need to improve existing and develop new designs of progressive water-saving equipment and irrigation technology, in relation to the natural conditions of Azerbaijan.
It is this approach to solving the problem of irrigated agriculture in Azerbaijan that can bring agriculture out of this critical state, that is, expand the cultivated area due to the saved water and get, along with the previously used areas, an additional stable high crop of crops. The use of this equipment in our country has not been given enough attention, although there is a shortage of water for irrigation that urgently required their use. Moreover, water-saving equipment and irrigation technology, providing plants with irrigation water in accordance with the course of their water consumption, also creates environmentally friendly conditions for the development and fruiting of crops. The advantage of this type of irrigation is that with a minimum supply of water, it creates conditions for an even distribution of moisture on the root system of the plant and the entire irrigated area. In this case, a microclimate and a moistening center are formed for a more intensive development of plants, therefore, it significantly increases the productivity of various types of crops.

Water-saving equipment and irrigation technology, in addition to those noted, has a number of other advantages over the existing surface irrigation method. It does not require strict planning of irrigated fields, it allows you to dose the irrigation rate and mineral fertilizers, to mechanize and automate the process of water distribution, etc. The use of water-saving equipment and irrigation technology in the conditions of privatization of land plots passing into private ownership is very important. It will be very profitable to water the largest areas of private farmland in conditions of water scarcity in the most economically cheap way, since a large sum of money will have to be paid for water. Obviously, the most economical and rational consumption of land will be beneficial to any landowner in order to obtain guaranteed high crop yields. It should be noted that Azerbaijan is one of the leading countries among the CIS in multistructure management.

The transition to multi-structured farming has found developers in the field of agricultural engineering not prepared for largescale development of agricultural machinery, including irrigation. Currently, there are not only sets of equipment for irrigation of small areas in various environmental conditions, but even a program for the development of the production of such equipment. The lack of special equipment leads to the use of inefficient manual labor or to the irrational use of traditional irrigation equipment, unsuitable for farms and household plots. For use in farmers and household plots, the Institute of Erosion and Irrigation of ANAS suggests using more effective means: micro irrigation and irrigation hoses. However, the Institute does not have the opportunity for a full set of equipment. Solving the problem of irrigation of farms and household plots at the level of developed capitalist countries requires a radical change in the existing principles of labor organization, territory and water use.

The analysis of the current state of irrigated farms and household plots (1996-2007) showed their low technical equipment, the lack 
of well-established production, and the completeness of equipment and oriented private land users. The statement of the problem of optimizing technical solutions for irrigation of small areas and the development of the production of various types of equipment for farms and household plots should be based on the following principles and basic principles. Irrigation equipment should provide a variety of technical solutions for pressure, flow, water distribution, level and degree of automation, cost the bridge of the complex and equipment enabling the land user to choose the most suitable technical solutions for his conditions.

Factors determining the choice of a technical solution ensuring environmental safety, resource conservation, simplicity and reliability in operation should be:

a. Natural and economic conditions of the site.

b. Regulated regime of water supply and irrigation source.

c. Mode of stay of the land user on the site and the time limit allocated for irrigation and maintenance of irrigation equipment.

d. Requirements of the land user to a complex of technological processes.

e. The possibility of changing the composition of crops cultivated on the site and providing adequate water for irrigation at the request of the land user.

f. Financing land user capabilities.

A prerequisite is the complete completeness and prefabrication of equipment, including the network, irrigation devices, controls, special equipment (hydraulic feeders, measuring instruments) pressure-forming devices, including storage tanks, etc.) A set of equipment must be installed on the water outlet to the farm, including a pressure regulator "after itself", a flow limiter, and a water meter. The kit guarantees the economical use of water in accordance with the agreed application and user requirements. Assessment of the applicability and selection of technical solutions for irrigation equipment, taking into account the complex of natural and economic factors and subjective requirements of the customer, can be carried out by the land user himself. The initial data for establishing the type of irrigation equipment are:

a) Characteristic of the irrigation object and the operating mode of the water source (irrigated area, daily evapotranspiration, daily source of water operation)

b) Mode of the land user's stay at the irrigation facility and requirements for the labor intensity of the irrigation process (frequency of stay on the site, time limit allocated by the land user for irrigation and equipment maintenance, allowable laboriousness of the technological process).

\section{Output Results Are}

a. Parameters of water use (the required daily and weekly net and gross water volumes, the intensity and duration of water supply on the site, the degree of correspondence of the intensity of water supply to the intensity of water consumption);

b. Type of control of the technological process of irrigation (automated, semi-automated).

The results obtained, taking into account the traditionally used natural and economic factors of the irrigated area (crop composition, soil type and water permeability, soil depth and salinity, groundwater depth, terrain, the availability of electricity), as well as the financing possibilities of the land user, allow you to choose the type of irrigation techniques for a particular site.

It should be noted that the Institute of Erosion and Irrigation of ANAS develops and implements a variety of designs of water-saving equipment and irrigation technology, namely:

a) Micro-sprinkling system for farmers and individual farms.

b) Pulse-local irrigation system for farmers and individual farms.

c) Fine irrigation system.

d) Drip irrigation systems, etc.

The above irrigation technique will allow you to increase productivity, save irrigation water, prevent soil erosion and flushing, therefore, to perform priority tasks to solve the problem of improving the efficiency of agricultural production. Watersaving equipment is environmentally friendly. Low-intensity water supply completely prevents the formation of puddles and erosion on the soil surface. A small range of changes in soil moisture creates conditions that exclude their salinization. Maintaining soil moisture at the optimum level will allow the accumulation of part of the natural slopes in the layer of active moisture exchange. It should be borne in mind that due to a more productive use of natural rainfall, the irrigation rate is reduced. This is the watersaving role of low-intensity irrigation technology. The long-term direction of exposure to the microclimate of the surface air layer is ensured by the continuous supply of water to plants. In this case, the air humidity in thermally stressed periods of the day rises by $10-20 \%$, and the temperature drops by $1-3^{\circ} \mathrm{C}$.

Favorable microclimatic conditions are created for activating the process of photosynthesis of plants throughout the entire daytime without falling off during hot hours, as is the case with traditional sprinkling.

Due to the increased humidity, evaporation from the soil surface is reduced. The low-intensity irrigation technology creates a unique opportunity to deal with atmospheric drought with dry winds. Low-intensity irrigation makes it possible to implement a fundamentally new technology of continuous application of weakly concentrated macro- and micronutrient fertilizers, means of chemicalization by means of dosed water together with irrigation water centrally from the head of the system. The implementation of these advantages requires creating economic prerequisites for the development of farms, consisting primarily in benefits for the 
acquisition of fixed assets, providing economic assistance for the creation of infrastructure. A special place belongs to the use of the results of scientific and technological progress in production based on the creation of small-sized highly efficient equipment with elements of automation of production processes, including for watering crops.

\section{Findings}

Taking into account the foregoing and taking into account the results of our numerous studies, it is planned to develop a modernly new design of water-saving, environmentally friendly machinery and technology for irrigation of crops in an insufficiently moistened zone tested on the example of Upper Shirvan, Cuba-Khachmass, Ganja-Kazakh region and etc. Therefore, to solve this problem, a specific assessment should be made on the natural factors that determine the further development of this project.

\section{References}

1. Aliev ZH, Aliev BH (2005) Irrigated agriculture in the mountain and foothill regions of Azerbaijan. Publishing House Ziyaya Nurlan pp. 330.

ISSN: 2574-1241

DOI: 10.26717/BJSTR.2019.21.003635

ZH Aliev. Biomed J Sci \& Tech Res

This work is licensed under Creative Commons Attribution 4.0 License

Submission Link: https://biomedres.us/submit-manuscript.php
2. Aliev ZH, Aliev BH (1997) The studies of the complex factors to system reliability micro irrigation for conditions is blazed-irrigated husbandries in Azerbaijan. SRI (There commendation) NPO Pulse p. 59.

3. (2002) International Center for Agricultural Research in arid regions in arid regions. In Umarov U, Karimov A, Taraz C (Eds.). (ICARDA) Irrigation regime and monitoring technique. IC AQUA.

4. Nosenko VF (1981) Irrigation in the mountains. Kolos Publishing House Moscow pp. 143.

5. Markov Yu A (1989) Irrigation of collective and household gardens in the Agropromizdat Leningrad p. 64.

6. Verigo SA (1977) Methodology for forecasting productive moisture reserves and assessing the moisture supply of crops. In Gidrometizdat L (Eds.). Collection of guidelines for the analysis and assessment of agrometeorological conditions pp. 143-164.

7. Mikityuk AV, Kazharov VM, Shugay PY (2007) Prerequisites for the creation of electronic soil moisture meters. 97-103.

8. Nosenko VF (1981) Irrigation in the mountains. Kolos Publishing House Moscow pp. 143.

$\begin{array}{ll}\text { BIOMEDICAL } & \text { Assets of Publishing with us } \\ \text { RESEARCHES } & \text { - Global archiving of articles } \\ \text { - Immediate, unrestricted online access } & \text { - Rigorous Peer Review Process } \\ & \text { - Authors Retain Copyrights } \\ & \end{array}$

